\title{
The "Salcher" landslide observatory-experimental long-term monitoring in the Flysch Zone of Lower Austria
}

\author{
M. J. Stumvoll ${ }^{1}$ (D) E. Canli ${ }^{1,2} \cdot$ A. Engels ${ }^{1} \cdot$ B. Thiebes $^{1,3} \cdot$ B. Groiss ${ }^{1} \cdot$ T. Glade $^{1} \cdot$ J. Schweigl $^{4} \cdot$ M. Bertagnoli $^{4}$
}

Received: 13 February 2017 / Accepted: 3 October 2019 / Published online: 10 December 2019

(C) The Author(s) 2019

\begin{abstract}
Shallow landslide processes in geologically prone areas are recognised to pose threat to both human life and property. As precipitation is one of the main triggers for landslides, hydro-meteorological interrelationships and related future changes regarding frequency and magnitude of landslide processes in particular are of major interest. Long-term monitoring investigations of active landslide sites can provide a better understanding of the kinematic behaviour and triggering conditions of slope instabilities induced by hydrometeorological patterns. In this study, we present the installation and first results of a long-term monitoring setup in the Flysch Zone of Lower Austria equipped with a large variety of combined hydrological and geotechnical measuring techniques. The geological unit of the Flysch Zone, characterised by high contents of clay and the corresponding weathering products, is exceptionally prone to earth and debris slides which are mostly triggered by heavy precipitation events or snow melting. The landslide under investigation is situated in the heterogeneous lithology of Flysch deposits, surrounded by private property and without any agricultural usage. There is evidence of landslide activity since the 1950s. As it is showing only moderate displacement velocities (max. $20 \mathrm{~cm}$ in 2009), it represents a predestined study site for a long-term monitoring and the testing of new monitoring techniques. One of the main aims of this study is to characterise the internal structure, assess the current landslide dynamics and to analyse recent process activity by means of surface and subsurface monitoring installations. Surface methods currently include terrestrial laser scanning, GNSS and total station measurements. With these, surface movement rates of approx. $12 \mathrm{~cm} / 6$ months have been detected in the most active part of the landslide. Inclinometer measurements together with results from core drillings and penetrations tests suggest a complex, rotational landslide system with different shear zones, consisting of a more active part in the upper $3 \mathrm{~m}$ underlain by a less active part down to 9-m depth. As this monitoring site is designed to be operated for at least 10 years, information about its structure and high-resolution, multi-temporal data about its dynamics can be correlated with hydrological cause variables in the future. These insights and the exemplary nature of the study site regarding shallow landslide processes in Flysch deposits will be useful for the development of novel analysis methods for both Lower Austria as well as study sites with similar initial conditions.
\end{abstract}

Keywords Long-term landslide monitoring $\cdot$ Shallow rotational landslide $\cdot$ Slow moving landslide $\cdot$ Surface and subsurface monitoring techniques $\cdot$ Landslide structure $\cdot$ Rhenodanubian Flysch Zone $\cdot$ Terrestrial laser scanning $\cdot$ Inclinometer $\cdot$ Core drilling · Penetration test

M. J. Stumvoll

margherita.stumvoll@univie.ac.at

1 Department of Geography and Regional Research, University of Vienna, Vienna, Austria

2 STRABAG AG, Subdivision Digitalisation, Wackersdorf, Germany

3 German Committee for Disaster Reduction, Bonn, Germany

4 Geological Survey, Office of the Lower Austrian Federal State Government, St. Pölten, Austria

\section{Introduction}

Landslides are natural phenomena that pose a substantial hazard and risk worldwide (Guzzetti et al. 1999). Seismic shaking and intense rainstorms are commonly the main triggering agents for landslide occurrences. Rainfall-triggered landslides frequently damage infrastructure and cause significant loss of life. Petley (2012) studied the effects of non-seismic-triggered landslides using a 7-year statistic (2004-2010) and approximated an average annual death toll of more than 4600 .

An increased number of landslides is frequently attributed to changing precipitation patterns; however, large uncertainties 
remain (Coe and Godt 2012; Crozier 2010; Gariano and Guzzetti 2016). To better understand recent and future frequency and magnitude relationships of landslides, long-term landslide monitoring systems are required (Thiebes 2012). Particularly, monitoring of active landslides can help to understand the hydrological and geotechnical interactions of a landslide subsurface (Malet et al. 2005).

A large number of methods have been utilised for landslide monitoring systems (Mikkelsen 1996; Thiebes 2012; Thiebes and Glade 2016). The methods can be categorised into approaches that analyse (a) the triggering factors, e.g. rainfall and changes of soil moisture conditions, or (b) the detection of landslide movements itself. Approaches to analyse triggering factors include direct measurements through e.g. piezometers to quantify groundwater tables (Massey et al. 2013), time domain reflectometry (TDR) probes to analyse volumetric soil moisture content (Camek et al. 2010), tensiometers for measuring pore water pressures (Montrasio and Valentino 2007) and non-invasive techniques like electrical resistivity tomography (ERT) which can give a spatially distributed estimation of soil wetness (Gance et al. 2016; Supper et al. 2014). Landslide movement monitoring includes both surface and subsurface methods. Traditionally, total stations (Burghaus et al. 2009; Reyes and Fernández 1996), as well as GNSSbased techniques (Corsini et al. 2012; Yin et al. 2010a; b), were the primary methods to measure surface displacements. In recent years, terrestrial laser scanning (Abellán et al. 2011; Canli et al. 2015), radar interferometry (Mazzanti et al. 2015; Monserrat et al. 2014; Mulas et al. 2015) and photogrammetry-based methods (Gance et al. 2014; Stumpf et al. 2015; Travelletti et al. 2008) have become popular because they are suitable for displacement measurements over wider areas. Inclinometers, either operated manually or automatic, remain somewhat the gold standard for monitoring of subsurface displacements (Bell and Thiebes 2010; Jongmans et al. 2008; Yin et al. 2010a).

Long-term monitoring systems of active landslides that combine hydrological and geotechnical monitoring with close-range remote sensing techniques are fairly rare, particularly in environments with a comparable complex lithological setting like the Rhenodanubian Flysch Zone. However, most of the complex, hydrologically triggered slope failures that are detected and described in previous studies in Austria are predominantly located in the Rhenodanubian Flysch Zone in Lower Austria and Vorarlberg (Petschko et al. 2013; Petschko et al. 2014; Tilch 2014; Tilch et al. 2013). Particularly the studies of Petschko et al. (2014) and Steger et al. (2016) highlight the high susceptibility to landsliding of the Flysch deposits in Lower Austria. In terms of its topographical and lithological characteristics, the location around the "Salcher", in the pre-Alpine region near Gresten, appears to be a representative area for slope failures in the Flysch Zone of Lower Austria. In this regard, it can be hypothesised that a monitoring setup of this kind is able to (a) provide useful information about long-term movement patterns in relation to potential triggers, such as rainfall or snowmelt, (b) evaluate innovative monitoring combinations, and (c) develop new landslide analysis methods transferable to similar landslide areas.

In this paper, we present the first results regarding characterisation and structure of a complex, rotational landslide in the Austrian Flysch Zone, which is currently being implemented for a long-term landslide observatory. Moreover, we highlight the advantages of combining hydrological and geotechnical monitoring and close-range remote sensing techniques in order to understand landslide movement and to predict potential instable areas. The future aim of the monitoring system is not only to improve the understanding of the landslide under investigation but also to develop and test new methods which then can be implemented on other potentially hazardous slopes, or might contribute to already existing systems. An outlook highlights the next steps of the implementation of a comprehensive monitoring system, which includes several novel approaches but also reliable traditional methods.

\section{Study area}

The study area is located in the western part of the Federal State of Lower Austria in the municipality of Gresten (Scheibbs district, Austria) (Fig. 1a). The study site of the Salcher landslide is located centrally in the municipality of Gresten (Fig. 1b) on a non-forested, east-facing slope at an elevation of approx. $500 \mathrm{~m}$ a.s.l. with slope angles between 10 and $20^{\circ}$. The size of the active landslide part is approx. $4000 \mathrm{~m}^{2}$. The lower landslide part is surrounded by two roads. Three residential buildings are situated underneath the main sliding direction of the landslide (Fig. 1c).

\section{Geology}

The geological setting of the study area is complex - and one of the most important pre-dispositional factors regarding landslide occurrence and activity in the region. Within a narrow band of about $2 \mathrm{~km}$, three different tectonic units are present. The Helvetic unit of the Gresten Klippen Zone (GKZ) is situated between the Penninic (Rhenodanubian) Flysch Zone (FZ) in the north and the (Upper) Austroalpine Northern Calcareous Alps (NCA) in the south-resulting in highly complex and diverse successions of various lithological units (details are provided in Ruttner and Schnabel 1988; Schnabel 1980; 1999; Schnabel et al. 2002). The GKZ forms several outcropping horizons (in German Klippen) originating from Jurassic and Lower Cretaceous deposits. Being part of the Helvetic Unit and originally deposited north of the (Rhenodanubian) FZ (Höck et al. (2005) citing Oberhauser 


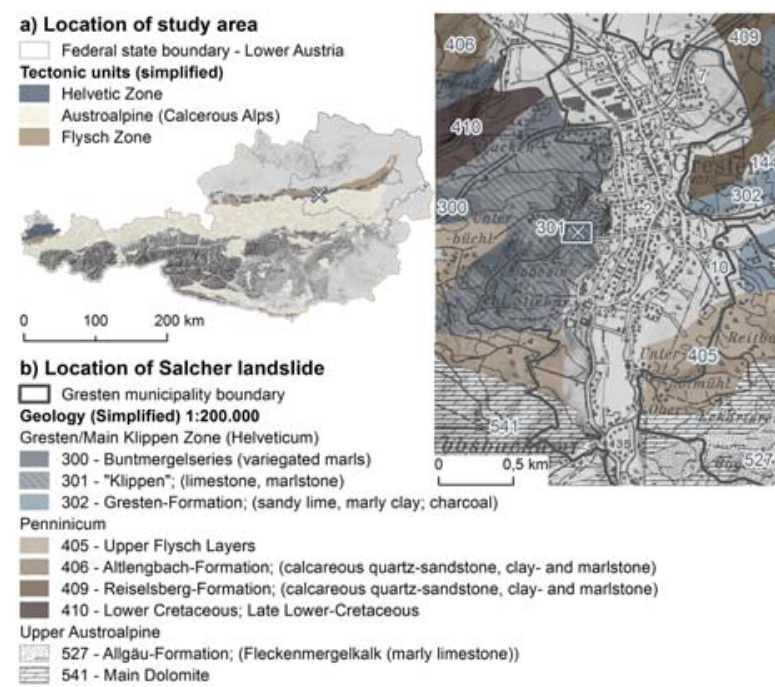

Fig. 1 a The study area is located in the western part of Lower Austria (DEM (Resolution $1 \mathrm{~m} / 10 \mathrm{~m}$ ): NOEL GV (2009)). b The Salcher study site is situated in the municipality of Gresten; the area is embedded in a highly diverse geological setting between the Flysch Zone, the Gresten Klippen Zone and the Northern Calcareous Alps (geological maps:

(1980) and Schnabel (1992)), the GKZ was entirely overthrusted by the FZ during the Alpine orogenesis. Whilst the GKZ is covered by variegated marls (in German Buntmergelserie) and composited mainly of rock types including clayey shales, marls, sandstones as well as conglomerates and breccia, the FZ - as such as well as the sheared scales of the FZ in the GKZ-is composited of marine sandstones, clays, clayey shales, marly shales and marly limestones (Fig. 1b). Both the GKZ and the FZ are extremely complex regarding stratigraphy, lithology and facies (see i.a. Ruttner and Schnabel 1988; Schnabel 1980; Thenius 1974; Wessely et al. 2006 for more details; Widder 1988). Due to the high content of clay and the corresponding weathering products as well as due to the fact that the pelitic layers are (geo-mechanically) tectonically extremely strained and deeply weathered, both the FZ and the Helvetic window of the GKZ are highly prone to landslide processes. Of the 1100 landslides registered in Lower Austria since 1965 until 2006, 62\% of them were reported in the Flysch (42\%) and Klippen Zones (20\%) (Gottschling 2006). Both units exhibit approximately five landslides per $\mathrm{km}^{2}$ in Lower Austria. The respective landslide inventory contains earth and debris slides mapped from a high-resolution LiDAR-DTM (NOEL GV 2009) and is described in detail by Petschko et al. (2013).

\section{Climate}

Being located in the northeastern alpine foreland, the study area is characterised by a warm temperate and humid climate. The mean annual air temperature is $7.0{ }^{\circ} \mathrm{C}$ and mean annual rainfall is $1212.9 \mathrm{~mm}$ (average of period 1981-2011). Heavy rainfall events exceeding $100 \mathrm{~mm}$ per day are likely to occur.

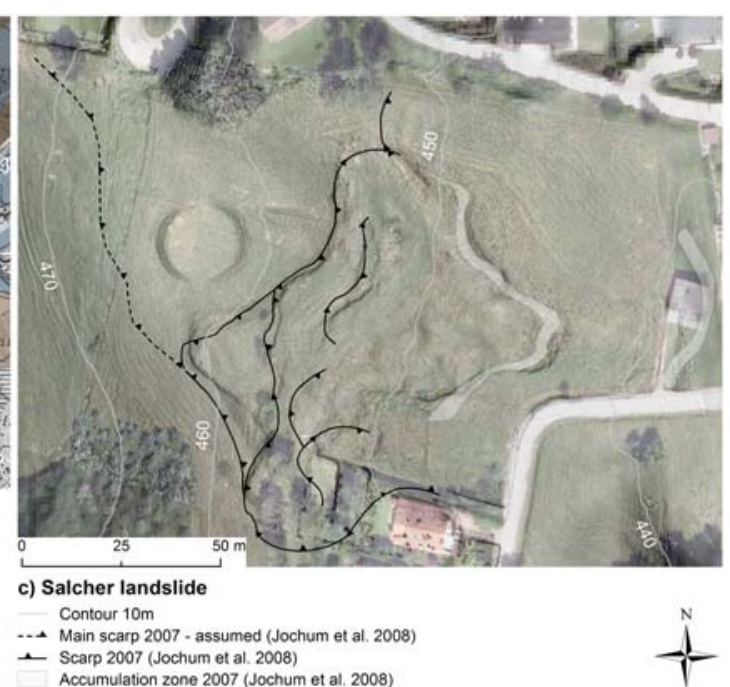

Schnabel et al. (2002); Weber (1997). c The Salcher landslide with an active area of approx. $4000 \mathrm{~m}^{2}$ is situated at an elevation of approx. $500 \mathrm{~m}$ a.s.l. (EPSG: 31256); the map is showing the geomorphological mapping results of Jochum et al. (2008)

Such events (e.g. September 6, 2007, (102 mm) and June 23, $2009,(111.5 \mathrm{~mm})$ ) caused major flooding and triggered landslides in Gresten and other parts of Lower Austria. In addition to strong rainfall events, rapid snowmelt has been identified as one of the main triggering factors of landslides in the region (Schweigl and Hervás 2009; Schwenk 1976, 1992).

\section{Historical information}

Prior to its initial activation, the Salcher slope was used as a skiing track from the 1950s onwards (Fig. 2). In the 1950s, skiing activities ceased due to repeated skewing of the lift pillars (Irmgard Plank, pers. comm. 2015). Initial significant slope movements were reported in July 1975. Heavy rainfall in the period between June 29 and July 3 in 1975 was assumed to be the triggering cause (Schwenk 1976). In autumn 1975, remedial measures on the Salcher landslide were carried out on the slope, comprising terrain levelling and filling of cracks. Although awareness of the problematic water conditions on the slope existed, countermeasures with respect to the implementation of an upslope drainage system were not realised. Three years later, parts of the landslide were reactivated by a heavy rainfall event on May 31, 1978. For this day, the rainfall record in nearby Randegg exhibited $101.9 \mathrm{~mm}$. Many other landslides and flooding were assigned to this extreme rainfall event, as it has also been the case in 1975 (Schwenk 1979). In the year 2000, parts of the upper landslide area were levelled out in order to use it as a vaulting area (Hans Plank, pers. comm. 2015) (see Fig. 1c). In the course of a rainy period in the first week of August 2006, repeated movements occurred. Rainfall measurements indicated $162.5 \mathrm{~mm}$ for the period between August 1 and 7, 2006. The movements caused the 


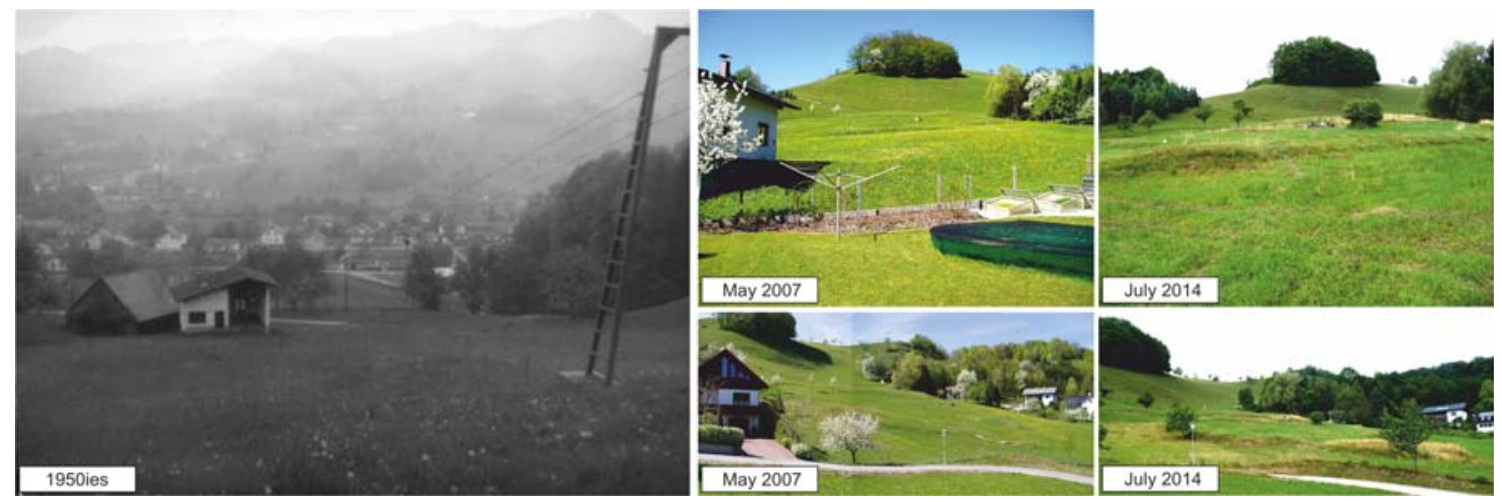

Fig. 2 Historical view of the Salcher landslide surface (roughly late 1950s) (Photograph: Marcel Mollik) on the left and the Salcher landslide surface in 2007 and 2014 on the right (Photographs: University of Vienna (2007/ 2014))

formation of tension cracks $20 \mathrm{~m}$ in length with fracture openings of $10 \mathrm{~cm}$. This was accompanied by the creation of fresh minor scarps and hummocks (Fig. 2).

During fieldwork for the current monitoring system in July 2014, a tree root sample was discovered in a drill core on the landslide in 2.6-m depth (see INC2/B4 in Fig. 5). Radiocarbon dating of the wooden sample revealed a calibrated date of $1670 \mathrm{AD}$ (with a conventional ${ }^{14} \mathrm{C}$ age of $265 \pm 30 \mathrm{BP}$ ). OxCal (Bronk Ramsey et al. 2013) with IntCal13 atmospheric curve (Reimer et al. 2013) was used for calibration. This is interesting for two reasons: (a) the oldest obtainable photographs of the Salcher slope (1950s) reveal already an entirely treeless surface, and (b) the depth and ambient material of the sample location, which represents a densely bedded, greyish and reducing environment, thus a long time of undisturbed groundwater conditions. This leads to a possible conclusion that the Salcher slope might have been forested once under relatively stable slope conditions and that the place of discovery was once overrun by the landslide.

\section{Previous monitoring activities}

After the reactivation in August 2006, the Geological Survey of Lower Austria set up geodetic piles for total station surveys of the area (see Fig. 5). Surveys started in April 2007 and were conducted biannually until November 2012. The survey campaigns revealed a total displacement of $0.925 \mathrm{~m}$ on the most active part of the Salcher landslide. However, measurements ceased in November 2012 as annual displacement rates between December 2009 and November 2012 totalled $5 \mathrm{~cm}$ only, whereas the displacement between April 2007 and December 2009 reached $4 \mathrm{~cm}$ per month on average (Schweigl 2013). ERT measurements, core drillings and penetration tests were carried out by the Geological Survey of Austria (GBA) and the University of Natural Resources and Life Sciences, Vienna (BOKU) in 2007 (Jochum et al. 2008). Additionally, a mineralogical characterisation of the drill cores was performed. Clay mineral analyses revealed an absence of smectite in the samples. The main mineral content among all samples was weakly crystallised kaolinite. Moreover, illite was determined in all samples. The general occurrence of chlorite in the deepest samples was explained by an early stage of weathering. The interpretation from ERT measurements pointed towards the existence of two shear surfaces and therefore two layers of different activity: (a) an upper active part of the landslide situated between 0 and $4 \mathrm{~m}$, and (b) a lower, currently inactive part between 4 and $9 \mathrm{~m}$. Based on penetration resistance, slope morphology and resistivity measurements, a weathering horizon between 9 and $14 \mathrm{~m}$ was suggested (see Jochum et al. (2008) for more details).

\section{Methodology}

In 2014, various field measurements consisting of devices for (a) surface (GNSS, total station, terrestrial laser scanning) and (b) subsurface investigations (dynamic probing heavy, percussion drillings, inclinometers) were conducted at the Salcher landslide, depicting the initial phase of the long-term monitoring site setup that is still in progress and connecting new measurements with historic information. This phase was accompanied by a couple of activities, ranging from preliminary desk study and field reconnaissance to concomitant laboratory and data analysis. Figure 3 shows the methodological approach of the monitoring setup and the workflow of the techniques used for this study.

\section{Desk study and geomorphological mapping}

Throughout the preliminary desk study, planning criteria for all further investigation stages were determined. A better understanding of the historical kinematics was necessary to specify the locations for subsurface investigations and later monitoring. Hence, it was required to assess available professional opinions, damage reports and findings from previous investigations to get an overview of the kinematic and morphological conditions and changes on the slope. 
Fig. 3 Methodological approach of the monitoring setup at the Salcher landslide starting in 2014

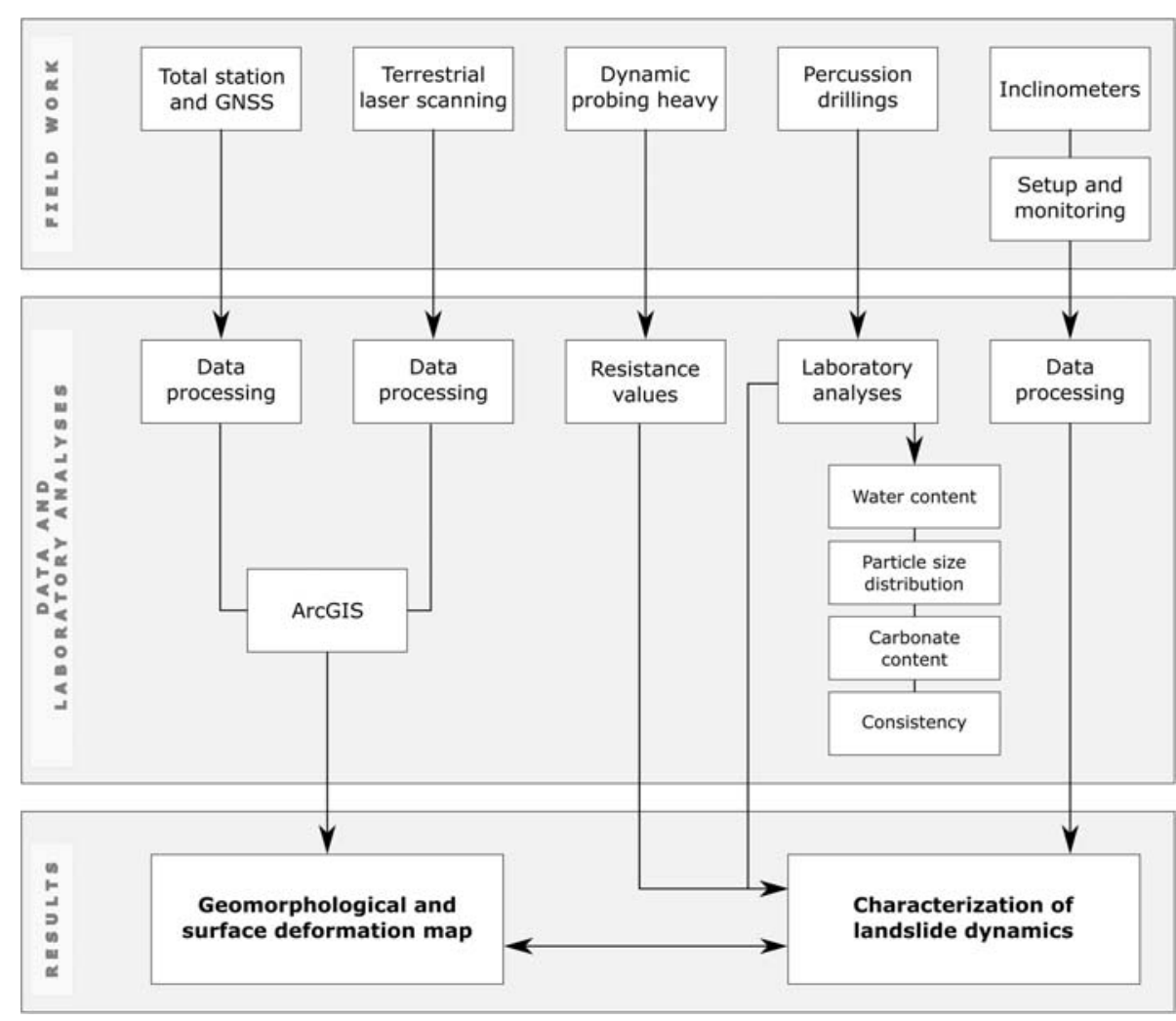

With the intention to identify surface displacement of prominent surface structures from an early stage of fieldwork, GNSS-based mapping was initially carried out in July 2014. Prominent morphological surface structures like scarps and areas of distinct morphology were surveyed with a Leica GPS 1200. Correction signals were obtained from the Austrian Positioning Service (APOS) that enable measurements with a $3 \mathrm{D}$ uncertainty lower than $1.5 \mathrm{~cm}$.

\section{Total station surveys}

The already installed network of geodetic benchmark piles (Schweigl 2013) was re-surveyed with laser distance measurements (see also Fig. 5) using a Leica TCRP 1201 together with reflecting prisms. The manual of the manufacturer indicates an accuracy of $1 \mathrm{~mm}$. Both, the GNSS and total station survey data, were visualised with ArcGIS.

\section{Terrestrial laser scanning}

Two terrestrial laser scanning (TLS) campaigns (October 2014 and December 2014) were carried out with a Riegl VZ-6000 (Riegl 2017) in order to obtain high-resolution, multi-temporal surface information. Additional TLS data was provided by the Geological Survey of Lower Austria
(2007; resolution $0.01 \mathrm{~m}$ ). Data acquisition was performed following a similar approach as Prokop and Panholzer (2009):

1. Location of suitable scan positions to minimise occlusions.

2. Improving the accuracy of the global scan positions and the coarse registration through mounting of a GNSS receiver (Leica GPS 1200; correction signals from Austrian Positioning Service (APOS)).

3. Choosing an appropriate point spacing $\left(0.035^{\circ} \mathrm{Theta} / \mathrm{Phi}\right.$ Finescan).

4. Acquisition of RGB information using the integrated camera of the Riegl VZ-6000.

Post-processing included registration (coarse and fine) and filtering (vegetation) using Riegl RiSCAN Pro processing software. Global position measurements were used for coarse registration. A first fine registration of each set of newly obtained point clouds from October and December 2014 respectively was carried out using the Multi-Station-Adjustment (MSA) in RiSCAN Pro (Iterative closest point algorithmICP — first introduced by Besl and McKay (1992)). To prepare the data for the MSA plane, surface patches were created using both a manual definition of corresponding plane surface patches (tieobjects) and the automatic plane patch filter in RiSCAN Pro. Results of the first MSA were used for a second 
MSA to register the different scanning campaigns (2007, October 2014, December 2014).

The RiSCAN Pro vegetation filter was used to get ground surface information only. After exporting the filtered point clouds for each of the three scan surveys, they were used for distance measurements calculations by creating DEMs of difference (DoD). Therefore, the point clouds have been converted to DEMs and hillshades using OPALS (Orientation and Processing of Airborne Laser Scanning data) software (Pfeifer et al. 2014). The DEMs have been created with a cell size of $0.1 \mathrm{~m}$. The differences in height ( $z$-axis) were calculated using ArcGIS.

\section{Dynamic probing heavy}

Dynamic probing heavy (DPH) was performed by using the SRS-15 (German type) penetrometer (Fig. 4a-c). The aim of this method was to detect changes in mechanical resistance of the subsurface material based on penetration tests (Springman et al. 2009). The device is pneumatically operated with a drop weight of $50 \mathrm{~kg}$. A cone with $43.7 \mathrm{~mm}$ in diameter and a dropping height of $500 \mathrm{~mm}$ ensured a standardised application according to the European Standard EN ISO 22476-2 for DPH. The number of blows required for each $10 \mathrm{~cm}$ was counted. Subsequent to every advanced meter increment, the rods were rotated to minimise skin friction.

\section{Percussion drilling}

Core drillings were carried out with a crawler drill GTR $780 \mathrm{~V}$ from Geotool. This augering technique is a common method for obtaining only slightly disturbed core samples (Van Den Eeckhaut et al. 2007). The rig can access moderately steep locations with little waterlogging (Fig. $4 \mathrm{~d}-\mathrm{f}$ ). It operates with a standardised weight of $63.5 \mathrm{~kg}$ and dropping height of $75 \mathrm{~cm}$. A casing drilling approach was applied to prevent
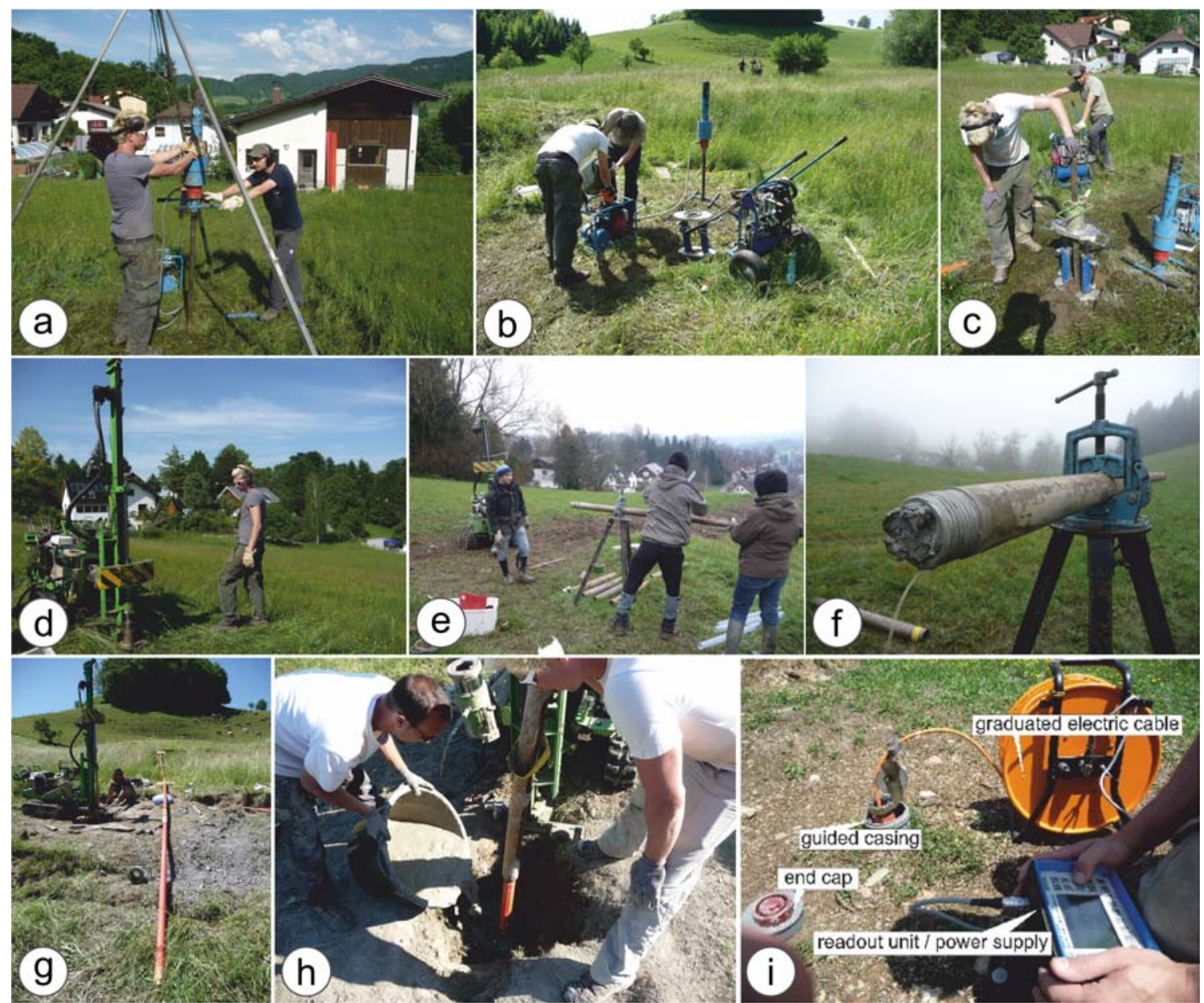

Fig. 4 Fieldwork on the Salcher landslide. a-c Dynamic probing on site DPH1. d-e Drilling operation with drill core extraction. $\mathbf{f}$ Water outburst of drill core B6. g-h Inclinometer installation with bentonite grout injection. i Inclinometer data acquisition (Photographs: University of Vienna (2014/ 2015)) 
borehole collapses and water inflow. In order to protect the drilling equipment, drilling progress stopped at a blow count of 100 for a $10-\mathrm{cm}$ increment. The probe was then extracted from the ground by a vertical-lift hydraulic tube clamp.

\section{Inclinometer}

Inclinometer casings obtained from "Glötzl Baumesstechnik GmbH" were used for field installation (Fig. 4g-i). The casings consist of flexible acrylonitrile butadiene styrene (ABS) compounds. Each casing is $3 \mathrm{~m}$ long and has a diameter of $55 \mathrm{~mm}$. The casings were riveted together to reach the respective final installation depth. The lower end was furnished with a plastic cap. Water tightness of the inclinometer casing was improved by wrapping plastic petrolatum tapes on a polypropylene fleece material base around the connecting elements. At the moment of final depth (reaching un-weathered rock), the drill pipe was removed and the casing was inserted and subsequently filled up with water. This way, potentiometric equilibrium with the surrounding was established. Care was taken to orientate the alignment of the leading grooves in direction of the estimated slope movement (Dunnicliff 1993). A tight connection between the casing and the surrounding stratum was achieved by using a bentonite-grout backfill (Bassett 2012).
The first inclinometer (INC1), installed in June 2014, was placed in the upper part of the currently active landslide part, where an anchorage below the suggested lower shear zone was achieved by reaching a depth of $13 \mathrm{~m}$. The inclinometer neighbours geodetic pile PF4 and corresponds to drill core B2 and the sites of dynamic probing DPH4, DPH12 and DP13 (see Figs. 5 and 6 for locations). INC2 neighbours PF3 and was drilled to a final depth of $6.5 \mathrm{~m}$. The site corresponds to drill core B4 and DPH8 and is intended to monitor the subsurface conditions near the right flank of the landslide body. INC3 was drilled to a final depth of $6.5 \mathrm{~m}$; the site corresponds to drill core B1 and DPH3 in the bulged area at the landslide toe. INC2 and INC3 were installed in September 2014.

Zero readings were performed after 3 weeks which allowed the borehole to settle and the bentonite-grout backfill to harden. Measurements were taken in $50-\mathrm{cm}$ increments using the NMG probe by "Glötzl Baumesstechnik GmbH". The probe measuring accuracy varies between 0.01 and $0.1 \mathrm{~mm}$ per measurement increment. In order to average errors, the probe was turned by $180^{\circ}$ before the second reading. Additionally, surface positions of the inclinometers were determined (Dunnicliff 1993; Stark and Choi 2008). Subsurface displacement was calculated using the software GLNP V4 by "Glötzl Baumesstechnik GmbH". Each measurement series was set in relation to the zero reading. Cumulative deformation curves

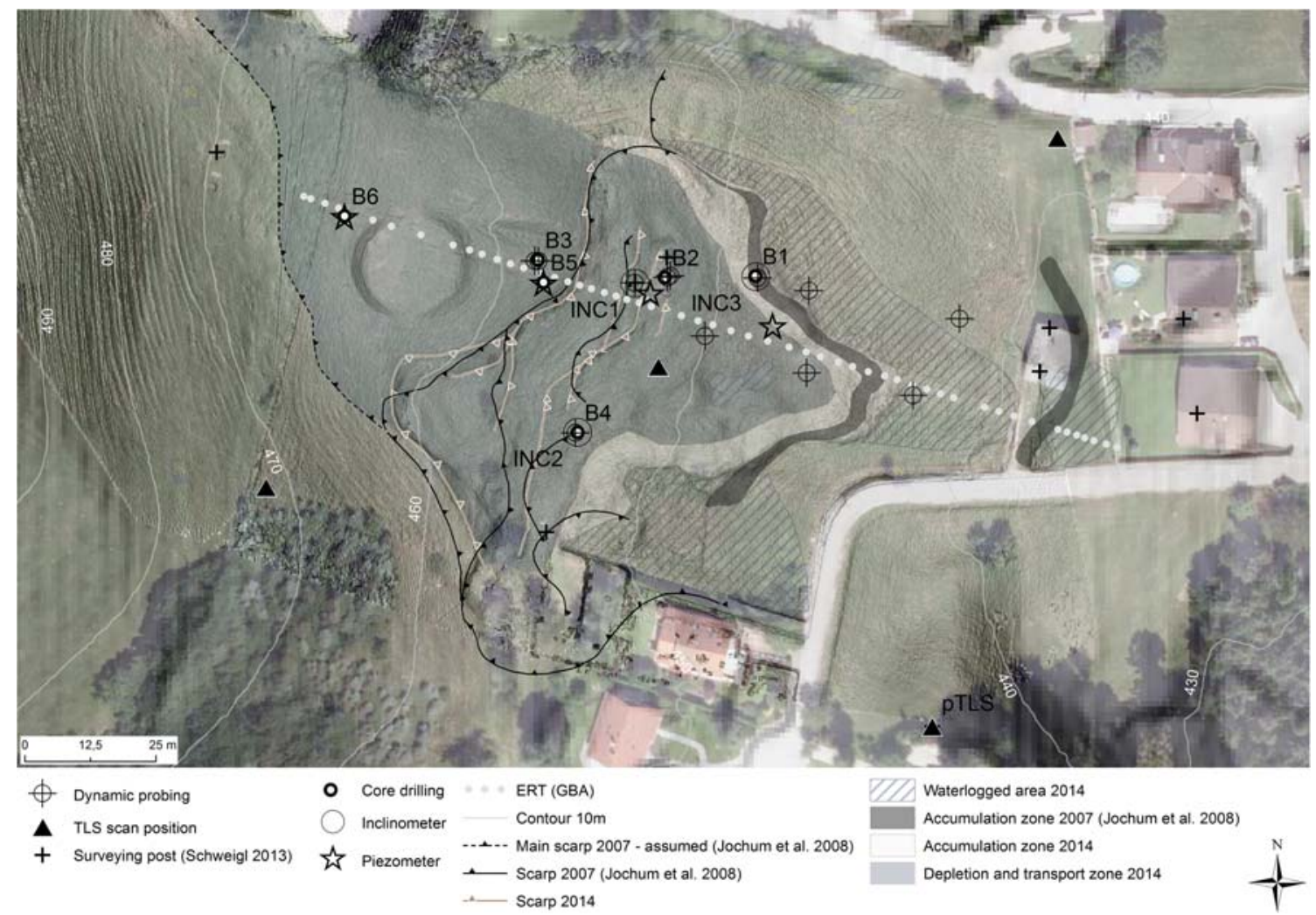

Fig. 5 Overview of surface and subsurface investigation sites and field installations (DEM (Resolution $1 \mathrm{~m}$ ): NOEL GV (2009); DEM (Resolution $0.10 \mathrm{~m}$ ): University of Vienna (2014)); Geomorphological mapping/investigation methods Salcher landslide from 2007: Jochum et al. (2008); Orthophoto: NOEL GV (2010)). For reasons of clarity, only the positions of the core drillings and the inclinometers are indicated 
were calculated, which visualise displacement values at corresponding depths.

\section{Core sample analysis}

The use of plastic inliners allowed continuous sampling of soil specimens in the lab, which permitted a soil physical characterisation of the material (Prinz and Strauß 2011). In the laboratory, particle size, natural water content, carbonate content and consistency were determined. The natural water content was determined according to Austrian standard for gravimetric and volumetric water content (ÖNORM L 1062). The state of consistency was investigated by kneading tests based on the German standard for soil classification in civil engineering (DIN 18196). Particle size analysis was performed by a combined sieving and sedimentation analysis. The samples were split into a coarse soil fraction $(>63 \mu \mathrm{m})$ and a fine soil fraction $(<63 \mu \mathrm{m})$. Sieve analysis of the coarse fraction was performed in accordance with ÖNORM L 1061-1. Sedimentation analysis of the fine fraction followed ÖNORM L 1061-2. For the sieve analysis, mechanical shakers and test sieves with $2 \mathrm{~mm}, 630 \mu \mathrm{m}, 200 \mu \mathrm{m}$ and $63 \mu \mathrm{m}$ opening diameter (DIN-ISO 3310/1) were used to derive the weight fractions of gravel, coarse sand, medium sand and fine sand.

The finer fractions of silt and clay were determined by using a particle size analyser. The respective diameter thresholds were set to $63 \mu \mathrm{m}, 20 \mu \mathrm{m}, 6 \mu \mathrm{m}$ and $2 \mu \mathrm{m}$ to establish comparability to the relevant Austrian standard. The SediGraph 5120 and auto sampler MasterTech 052 from Micromeritics were used for analysis. The machine performs X-ray monitored gravity sedimentation to determine the particle size, which resulted in cumulative finer mass percent versus particle diameter, assuming spherical diameter. Prior to analysis, fine soil samples were treated with $0.1 \%$ Tetrasodium pyrophosphate, which acts as a deflocculant for clays and prevents coagulation. Additionally, ultrasonic sound was applied before sedimentation analysis to break agglutinated grain matrixes. Granulometric curves were then calculated for each sample. The soil type was determined by plotting the textural composition on the Austrian soil textural triangle.

\section{Results}

In several field campaigns between July 2014 and February 2015, dynamic probing, core drillings, the installation of inclinometers, terrestrial laser scanning, total station surveys and inclinometer data acquisition were carried out on the Salcher landslide. Six boreholes (B1-B6) were drilled, thirteen sites were investigated with DPH and three inclinometers (INC1INC3) were installed (Fig. 5).

\section{Geomorphological mapping}

GNSS-based mapping during July 2014 revealed surface morphological observations to be very consistent with the findings from Jochum et al. (2008) in 2007. Heavily waterlogged areas in the perimeter of the lower bulged area were determined (see Fig. 5), with the frontal part of the landslide overall being slightly more pronounced than in 2007. Slightly below the vaulting area, several scarps are visible. The missing vegetation and rough surface morphology indicate higher landslide activity in these parts. The upper and lower boundary of the depletion and transport zone (Fig. 5) was delineated by the currently invisible main scarp, as suggested by Jochum et al. (2008), and the lower bulged area. Altogether, the currently active landslide area was calculated to cover approx. $4000 \mathrm{~m}^{2}$. The uppermost visible scarp of the landslide is approximately $110 \mathrm{~m}$ long whereas several minor scarps delimit a structure that resembles characteristics of a rotational landslide head. An inclined concrete foundation (a remnant of the skiing lift) on top of the head is turned against the hill by approximately $20^{\circ}$ (not distinguishable in Fig. 5, see SLF in Fig. 6). The steep landslide toe is pointing towards east and stops at approximately 30-m distance to the former lift house. Since 2007, the toe area remained stagnant in its location, but steepened quite significantly. Apart from some very steep areas, the mostly hummocky landslide surface is densely vegetated with grass. The scarps are mostly free from vegetation, indicating recent activity. The waterlogged areas are covered with patches of Juncus effuses, an indicator plant for standing groundwater.

\section{Total station surveys}

Discontinuous total station measurements performed since 2007 showed highly variable displacement rates. The most active part of the landslide revealed movement rates up to an average of almost $4 \mathrm{~cm}$ per month between July 2008 and December 2009, whereas displacement between December 2009 and November 2012 was on average lower than $0.5 \mathrm{~cm}$ per month. A continuation of total station measurements at the persisting geodetic network started in January 2015. The results indicate substantial movements of PF3 and $\mathrm{PF} 4$, which showed displacements of $10.9 \mathrm{~cm}$ and $45.7 \mathrm{~cm}$, respectively, corresponding to approximately 0.5 and $2 \mathrm{~cm}$ on average per month (Fig. 6). These values are in respect to the previous measurements from December 2012. The total

Fig. 6 Results from total station measurements at the Salcher landslide (2007-2015, different time lapses) including the caps of the inclinometer casings INC1-INC3, the lift foundation in the middle of the slope SLF (see also Fig. 2) and two of the surveying posts (PF3 and PF4) (DEM (Resolution $1 \mathrm{~m}$ ): NOEL GV (2009); DEM (Resolution $0.10 \mathrm{~m}$ ): University of Vienna (2014)) 

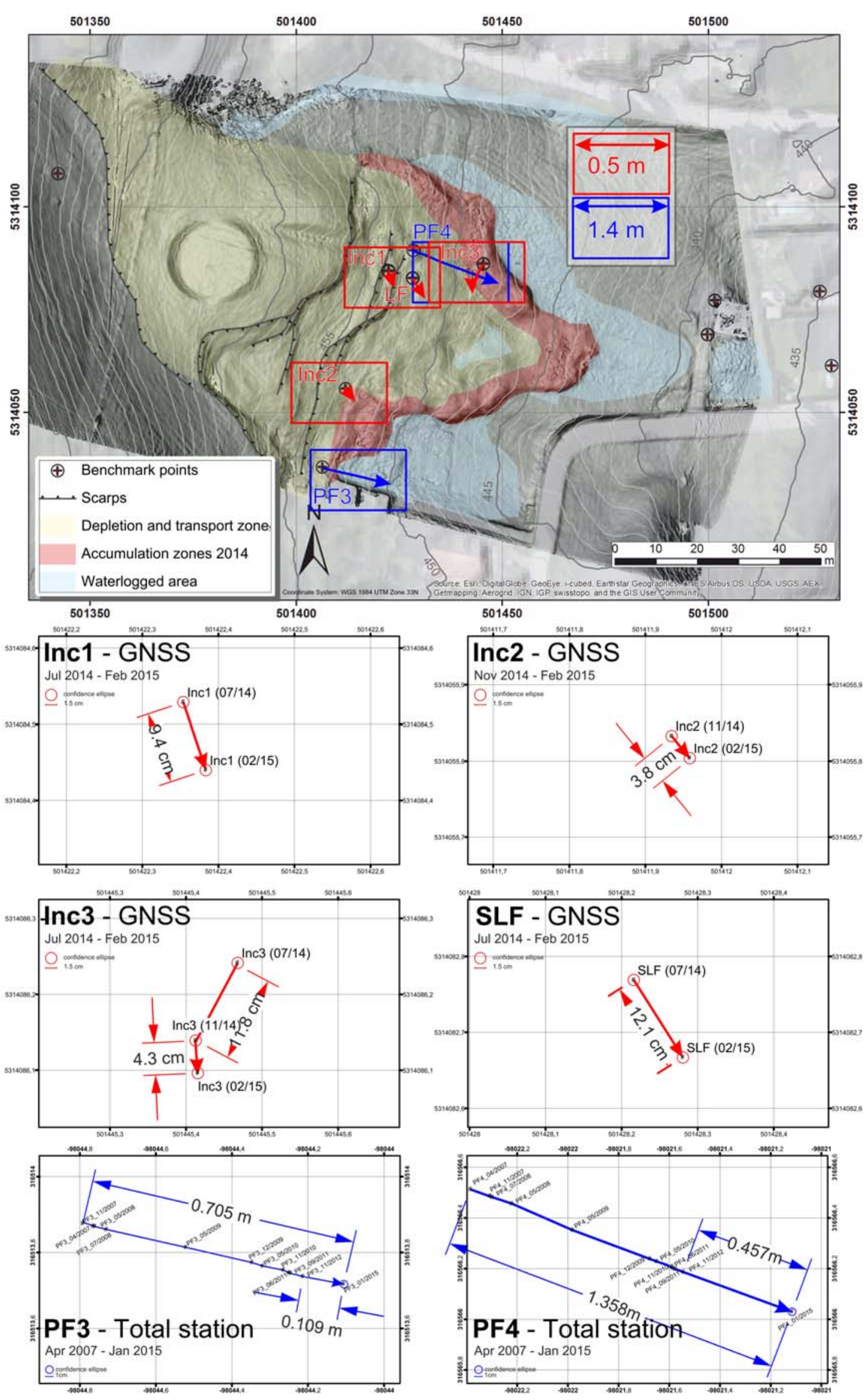
displacement at the most active part of the landslide surface was captured at PF4 with $1.36 \mathrm{~m}$ since April 2007. The southeast trend of the deformation of PF3 and PF4 is consistent for all measurements that were performed since 2007. PF2 heaved quite significantly until January 2015, when total station measurements reveal a vertical difference of $5.1 \mathrm{~cm}$ in comparison with 2012. Two benchmark points were mounted on the former ski-lift house that showed displacements of $1.4 \mathrm{~cm}$ with respect to 2012. Total station measurements were performed assuming PF5 (same position as pTLS scan position in Fig. 5) and PF1 (uphill of the landslide, not displayed in Fig. 5) to be stable over time. However, benchmark 103 and 104 showed deviations of 1.4 and $1.2 \mathrm{~cm}$ in southern direction. Both benchmark points are located on the walls of the buildings east to the ski-lift house below the landslide.

\section{Terrestrial laser scanning}

The RiSCAN Pro terrain filter removed all non-surface points. The dense grass cover was problematic; however, both newly obtained scans as well as the scan from 2007 were performed outside the growing season (spring 2007; October and December 2014), so grass vegetation remained more or less the ground surface. By using the automatic plane patch filter in RiSCAN Pro, the first registration error was in the range of 20-30 mm. After manually defining 10 plane patches distributed across the point cloud additionally (mainly on artificial structures such as house walls or streets that are available at the lower margin of the landslide), the final standard deviation of error could be reduced to $10 \mathrm{~mm}$. For further analyses, filtered point clouds were used for creating a DEM of difference (DoD).

In this study, the DoD between 2007 and December 2014 is presented. It revealed an elevation loss along the currently visible scarps up to $75 \mathrm{~cm}$ (Fig. 7). Accumulation was identified below the crescent course of the uppermost visible scarp and on the landslide surface that was subject to bulging of slope material. Accumulation was also determined along the toe area of the landslide (up to $85 \mathrm{~cm}$ ). Nevertheless, these values need to be interpreted with caution, as some uncertainties remain due to possible differences in grass vegetation, registration errors and DEM surface interpolation. However, the overall pattern is in accordance with the findings of the geomorphological mapping that was done previously and the interpretation of historical photos.

\section{Inclinometer measurements}

Given the average inclination of the three inclinometers, which is below $5.5^{\circ}$, an overall measuring accuracy margin of 0.01 to $0.1 \mathrm{~mm}$ per measuring step was achieved. In accordance with this benchmark, an error margin of 0.26 to $2.6 \mathrm{~mm}$ was attained in INC1, 0.13 to $1.3 \mathrm{~mm}$ in INC2 and INC3, respectively (Bell and Thiebes 2010).

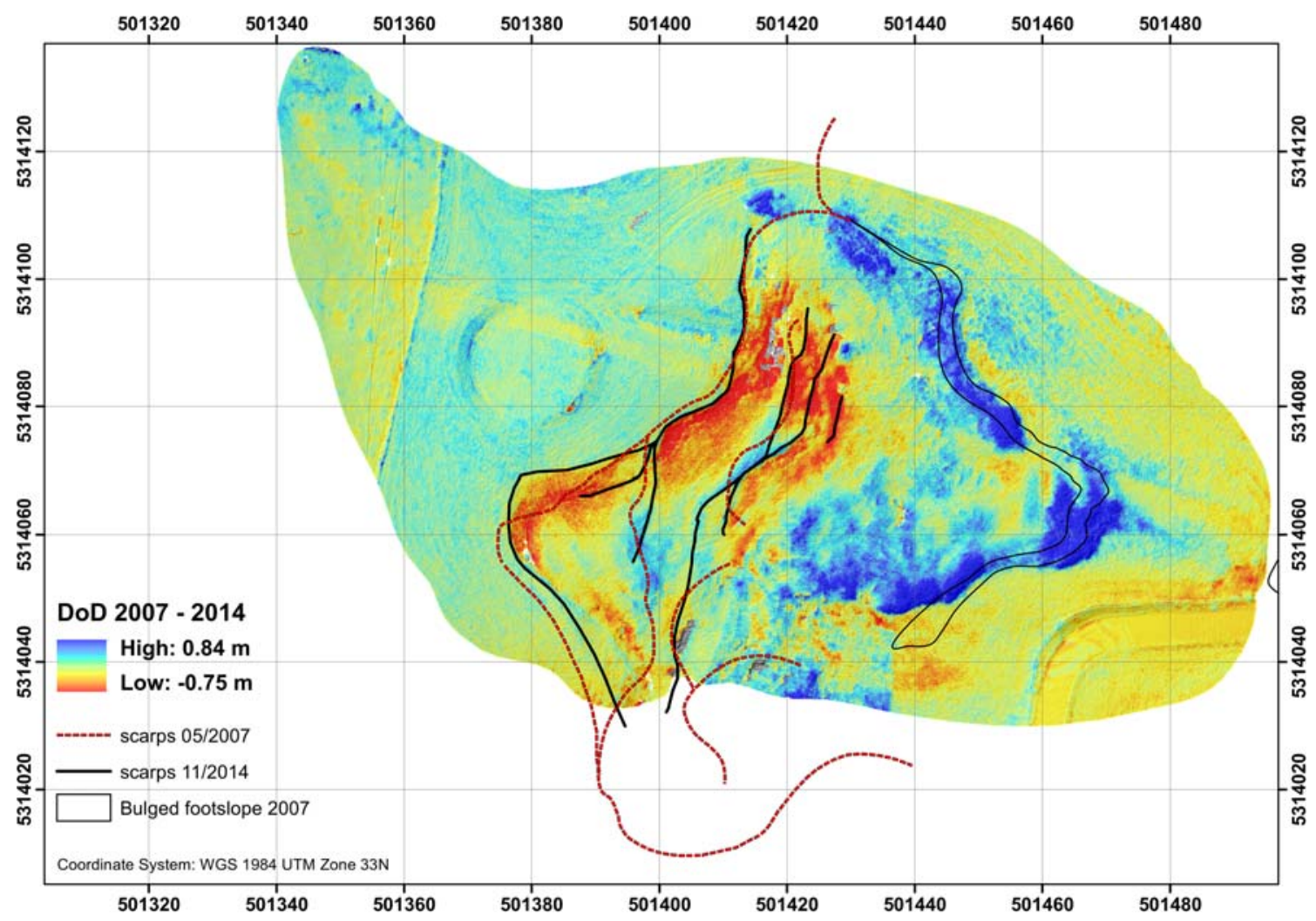

Fig. 7 DoD based on TLS point clouds obtained in 2007 and 2014 (DEM (Resolution 0.10 m): University of Vienna (2014)) 
INC1 Manual inclinometer measurements of INC1 commenced in July 2014. The reading in September 2014 already showed 6-mm downslope displacement at 3-m depth. The reading in January 2015 revealed substantial deformation at 3-m depth. In the time period of July 2014-January 2015 (189 days), INC1 recorded a cumulative displacement of $38.8 \mathrm{~mm}$ in downslope direction ( $A$-axis). The perpendicular movement component, which is measured along the $B$-axis, revealed little to no deformation (Fig. 8). The final reading reported here was carried out in February 2015 and confirmed this evaluation. An additional displacement of $0.6 \mathrm{~mm}$ lies within the error margin; hence, no change to the reading in January could be determined.

The first zero readings of INC2 and INC3 were carried out in September 2014. The top of the flexible inclinometer casing was subject to minor pulling forces, which occurred when the probe was lifted to the top. The slight bending of the deformation curve in the uppermost meter was caused by this and should therefore be neglected.

INC2 In January 2015, measurement revealed substantial displacement at 3-m depth (Fig. 8). A maximum lateral displacement of $44.2 \mathrm{~mm}$ was detected at 2-m depth. Compared with the downslope component of the movement, negative $B$ values of approximately $2.6 \mathrm{~mm}$ indicate a minor trend towards the north.

INC3 Zero readings of INC3 were performed in September 2014. Similarly to INC2, slight bending of the top of the casing could be seen in the form of minor deflections in downslope direction. Hence, the uppermost measurement was neglected for interpretation. Manual inclinometer measurements in January 2015 revealed downslope displacements, which were confirmed in the February readings. A deformation of approximately $18.9 \mathrm{~mm}$ in positive $A$-direction and $4.3 \mathrm{~mm}$ in positive $B$-direction could be limited to the zone between 1- and 2-m depth.

\section{Core sample analysis}

Soil physical properties (particle size, water content, carbonate content, consistency state) of six drill cores were investigated, three of them are presented here. The location of the drill sites is indicated in Fig. 5.

B1 For drill core B1, a total of 17 samples were extracted, based on transitions in colour and consistency state. According to the Austrian ÖNORM L1050, soil samples were classified as loam, loamy clay, silty loam, sandy loam and loamy silt (Fig. 9).

The clay fraction varied between 21.5 and $47.9 \%$. Silt takes the largest share in the overall particle size distribution of B1. Whereas the highest values of $66.4 \%$ were found in the deepest samples between 4.6 and $5 \mathrm{~m}$, the lowest values were found within the uppermost meter and range from $29.1 \%$ at $0.3-\mathrm{m}$ depth to $34 \%$ between $0.7-$ and $1-\mathrm{m}$ depth. Sand is present in smaller proportions, ranging from 3.6 to $17.4 \%$. Soil skeleton portion varied between 35.8 and $0.2 \%$, and was highest in the uppermost samples. Figure 10 summarises particle size, corresponding water content, penetration resistance and carbonate content, obtained from drill core B1, which can be assumed representative for all drilling sites. The water content varied strongly between the uppermost $1.5 \mathrm{~m}$ and the lowest samples. Highest values and very soft consistency were determined in the uppermost samples and reached $34.4 \%$. The lowest values corresponded to the deepest samples and totalled 7.8\%. Apart from elevated levels at approximately $3-\mathrm{m}$ depth, a steady decline towards the bottom of the soil column can be observed. This is in agreement with the constantly increasing blow count of DPH3 at approximately 3-m depth.

B2 As seen in B1, the soil samples in B2 were purely cohesive, highest in silt content and exhibited clay values reaching up to $43.6 \%$. Lowest clay values of $14.1 \%$ were determined between 2.8 and $2.95 \mathrm{~m}$. Within the next $5 \mathrm{~cm}$, however, a sharp change to loam was determined (Fig. 11). The loamy sample is marked by its stiffness and greyish reduced colour.

B4 Compared with the other drill cores, the water content of B4 was consistently high and exceeded $40 \%$ at $0.5 \mathrm{~m}, 2 \mathrm{~m}$ and $3.5 \mathrm{~m}$. The overall cohesive soil samples therefore showed very soft and even slurry consistence. Between 3.45 and $4 \mathrm{~m}$, as well as just below the surface, clay was generally lower compared with the other drill cores.

The synthesis of all drill core analyses is shown in the proposed underground model for the Salcher landslide in the discussion part (Fig. 12).

\section{Discussion and conclusions}

Over the period of 7 years of total station monitoring, PF3 and PF4 represented by far the most active zones of the landslide. Current total station measurements of the benchmark piles confirm recent slope displacements similar to the most active period in 2009. Particularly PF4 showed surface deformation values of approximately $20 \mathrm{~cm}$ per year. However, the surveying interval of 2 years does not permit drawing conclusions on a steady movement rate. It is also possible that a sudden displacement of $40 \mathrm{~cm}$ occurred in the course of 2 years. Apart from this, the formation of new tension cracks occurred below the proposed landslide head and indicated the highest activity in this area as well. Based on the findings of the TLS change detection and GNSS measurements, the most active area of the landslide was allocated in the immediate vicinity of PF4. 


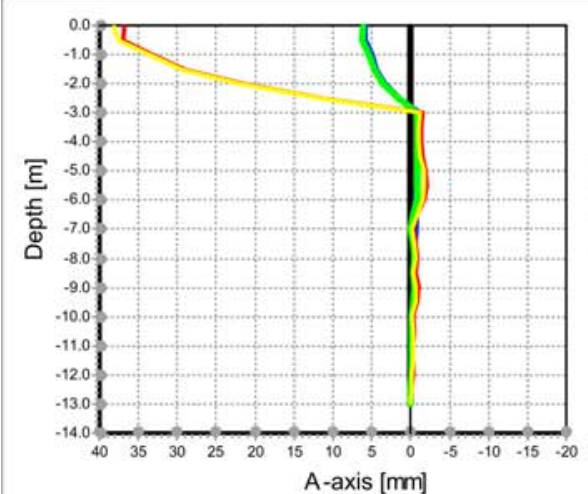

Inc1 $13.0 \mathrm{~m}$ depth

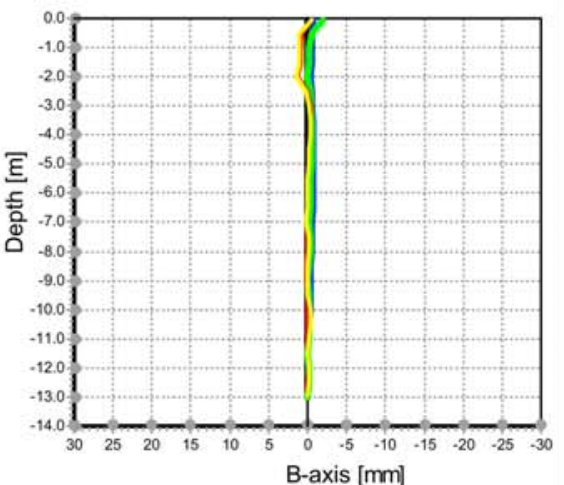

July 24, 2014

Diff.days

Sep 24, 2014 - July 24, 2014

Oct 17, 2014 - July 24, 2014

Jan 29, 2015 - July 24, 2014

Feb 10, 2015 - July 24, 2014

0

62

85

189

201

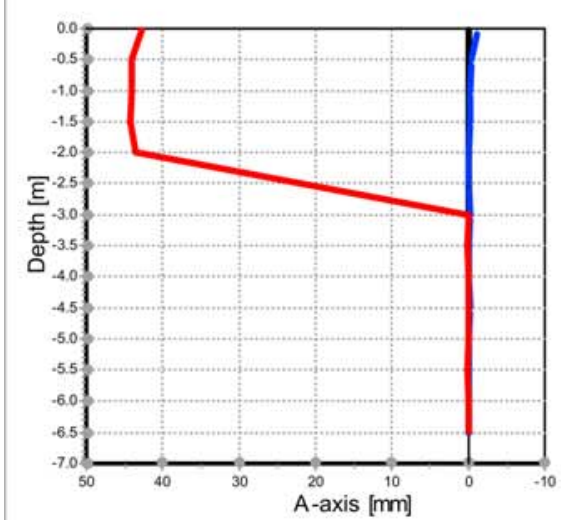

Inc2

$6.5 \mathrm{~m}$ dept
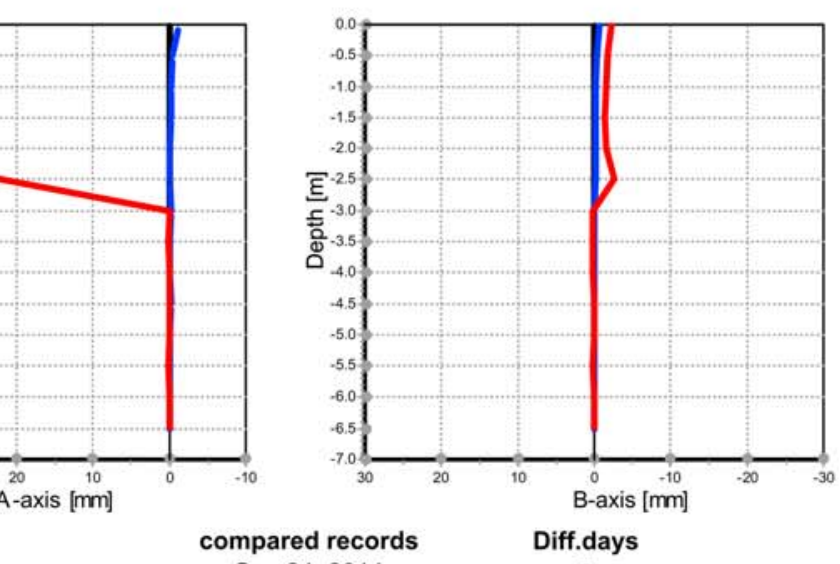

Sep 24, 2014

Diff.days

Oct 17, 2014 - Sep 24, 2014

0

23

Feb 10, 2015 - Sep 24, 2014

139
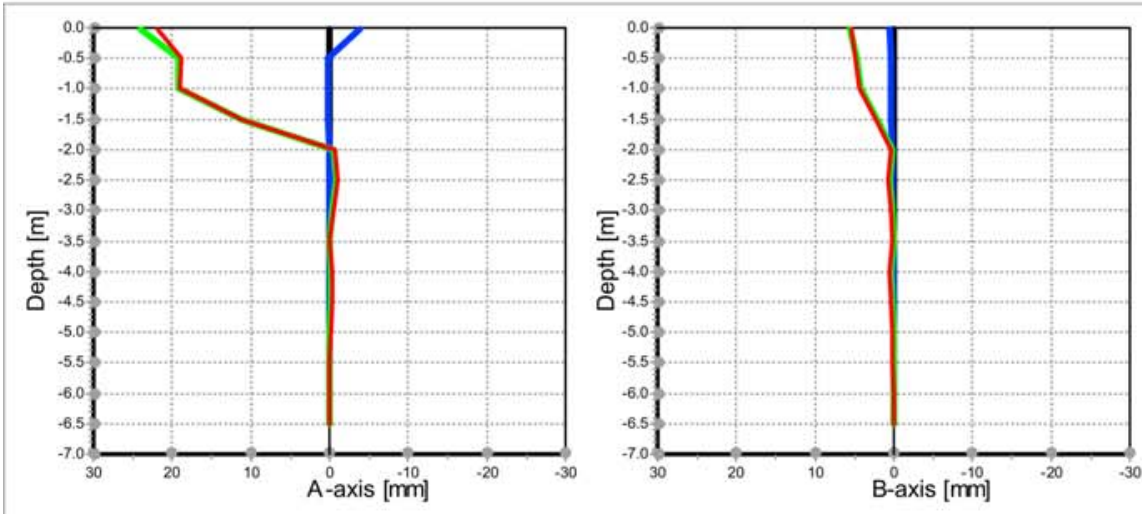

Inc3

$6.5 \mathrm{~m}$ depth

\section{compared records}

Sep 24, 2014

Oct 24, 2014 - Sep 24, 2014

Jan 29, 2015 - Sep 24, 2014

Feb 10, 2015 - Sep 24, 2014
Diff.days

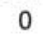

23

127

139 
Fig. 8 Results of inclinometer measurements (INC1-INC3) at the Salcher landslide for different time lapses between 2014 and 2015 (locations shown on Fig. 5)

Substantial change in aforementioned areas can also be seen in a comparison of oblique imagery of the slope.

Surface morphological information, together with data from core analyses, penetration resistance and inclinometer measurements, was used to create an underground model of the landslide. The proposed model (Fig. 12) suggests that the landslide consists of several interconnected sliding bodies, altogether resembling the geometry of a larger rotational landslide. The area between the visible scarps and the bulged foot slope exhibits structural characteristics of a translational landslide. The deepest shear zone was determined at approximately $8-9 \mathrm{~m}$ below the surface of the slope concavity. The course of its upper end was drawn based on surface observation and an assumed gradient, which was derived from core analysis. The courses of the minor scarps were derived from local displacement measurements by inclinometers and the structural interpretation of drill core data. The remaining course of the shear zone was constructed based on the interpretation of the surface morphology and blow count values from dynamic probing. The depth of the shear zone in the lower part of the depletion and transport zone and the bulging zone of accumulation was derived from dynamic probing data and displacement measurements in INC3.

Inclinometer-derived movement data demonstrates ongoing movement over the course of the study starting in June 2014. Core drillings and inclinometers reveal information only at single point locations, limiting their informational value. However, for the time of inquiry, INC1 and INC2 underwent a downslope displacement of approximately $4 \mathrm{~cm}$ and $2 \mathrm{~cm}$, respectively. It could further be concluded that movements in the zone of depletion and transport zone occurred within narrow bands of approximately $1-\mathrm{m}$ thickness in a depth of $3 \mathrm{~m}$ in the case of INC1 and INC2, and at 2-m depth in INC3. This is interpreted as the existence of a traceable sliding plane over a longitudinal section.

For the drill cores B1, B2 and B4, a depth-related correlation to elevated clay content can be shown. Clay-rich soil materials usually undergo a reduction of shear strength over the course of shear processes and residual strength is usually lower due to decreased friction angles. With respect to the composition of the materials in the clay fraction, reference could be made to the findings from Jochum et al. (2008), whose investigations indicated a dominating presence of weakly crystallised kaolinite throughout depth. In conclusion, it can be stated that all of the sampled drill cores showed textural heterogeneity which is interpreted as signs of dynamic behaviour, which cannot be explained by soil diagenetic aspects alone. Movements are assumed to be triggered upon saturation of identifiable clay-rich layers, which were determined at 2-m depth in drill core B1, and at approximately 3-m depth in drill core B2 and B4. The findings in this study further revealed that the transient parameter water content could not be used to gain straightforward information on the landslide structure. This could be seen in layers, which were underlain by clay-rich aquiclude layers. The samples of these layers do not indicate accumulation trends of percolating water above impervious beds. Given the relatively high permeability of the lowest sections of drill core B3, elevated water contents were to be expected above the stiff to hard layer at $8.5-\mathrm{m}$ depth. Despite the use of sealed plastic inliners, evaporation must be taken into account in the 2-month timespan between sampling and laboratory analysis of the drill cores. Core loss and resulting empty space in the inliners might have favoured the outgassing of the liquid phase even further. Due to the fact that little core loss was experienced in drill core B4 and that less time had elapsed between sampling and analysis,
Fig. 9 Drill core samples from drilling site B1 with the corresponding soil textures (according to ÖNORM L1050)
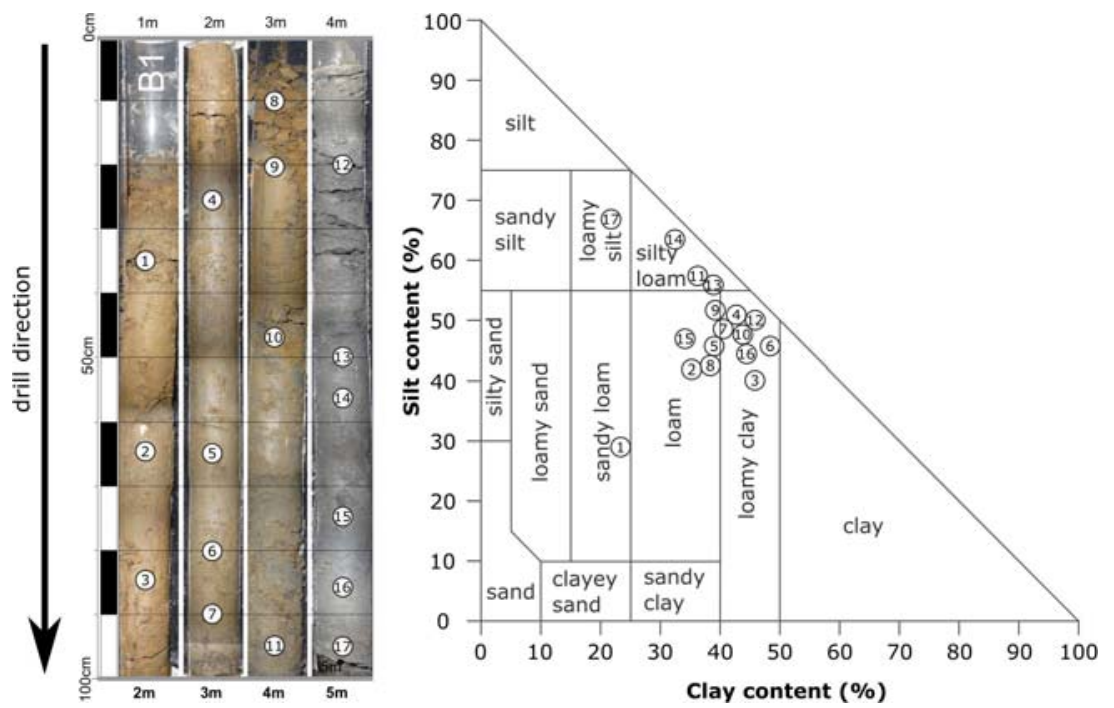


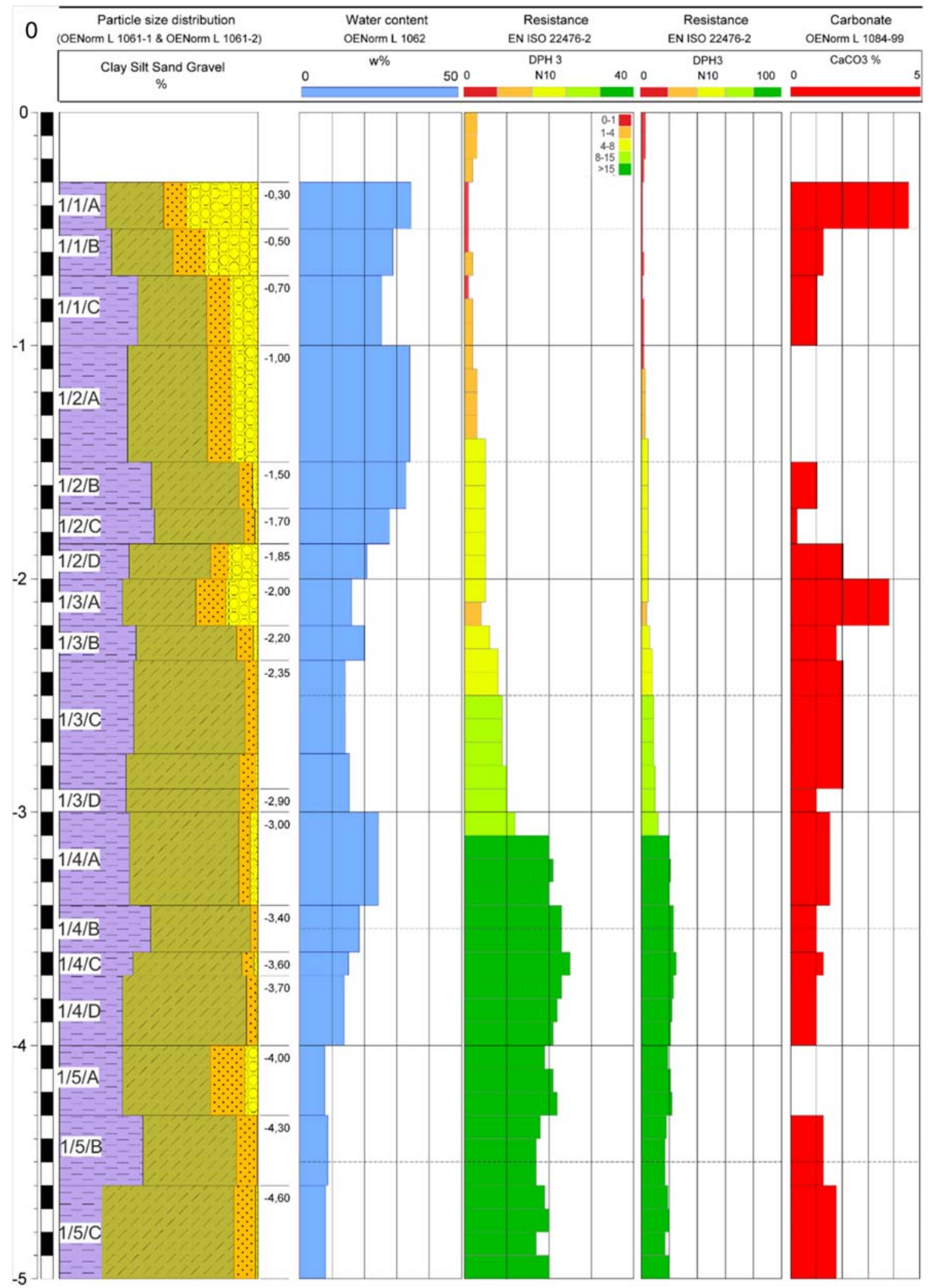

Fig. 10 Visualisation of particle size, water content, penetration resistance and carbonate content at corresponding depth in B1

the water content in B4 could be used to demonstrate accumulation trends above the depth of $3 \mathrm{~m}$. However, B4 was drilled without a casing, and its drilling was performed several weeks after the drilling of B1-B3. Hence, it cannot be ruled out that water from a perched water table may have biased the results in B4. Likewise, it has to be assumed that different 
Fig. 11 Textural transition in

2.95-m depth in B2

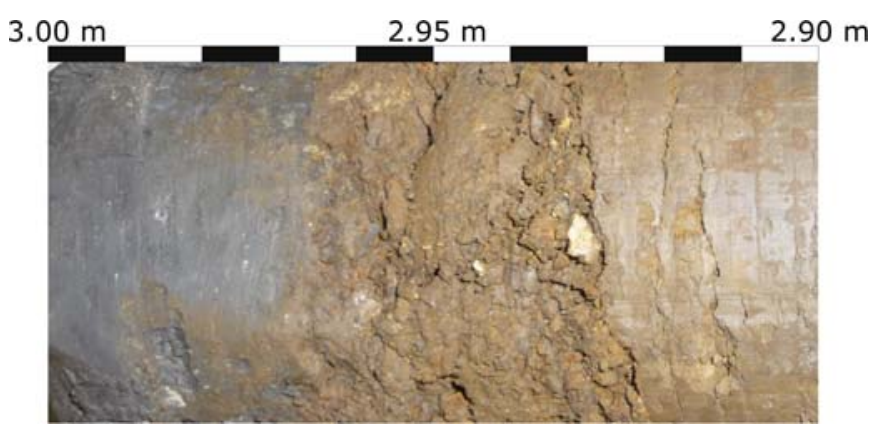

landslide. However, conclusions towards future slope stability or even triggering conditions cannot be drawn yet. In addition, the discontinuous surface and subsurface measurement intervals of the installed devices aggravate any further predictions. Yet, the preliminary findings of this study highlight that a combination of a variety of different monitoring equipment lead to valuable insights of the dynamics and subsurface behaviour of an active landslide and its responses towards potential triggering events. This highlights the importance for long-term monitoring efforts for active and complex landslides in order to estimate or predict future slope stability variations.

An important issue not yet addressed in this study is the hydrology of the Salcher landslide. It is expected that a permanent ERT, which only recently has been installed along the entire length of the slope, will deliver interesting insights into the hydrologic response behaviour. Measurement interval for the ERT is currently at $3 \mathrm{~h}$. Likewise, a recently installed weather station and implemented piezometers for measuring changes in ground water level are expected to enable investigations on the hydraulic response of the slope in near future. Additionally, TDR probes in different depths are installed for

The first months of ongoing fieldwork revealed first approximations of the internal structure and the dynamics of the Salcher

Fig. 12 Proposed underground model of the Salcher landslide based on obtained sub-surface information (inclinometers, drill cores, penetration resistance)

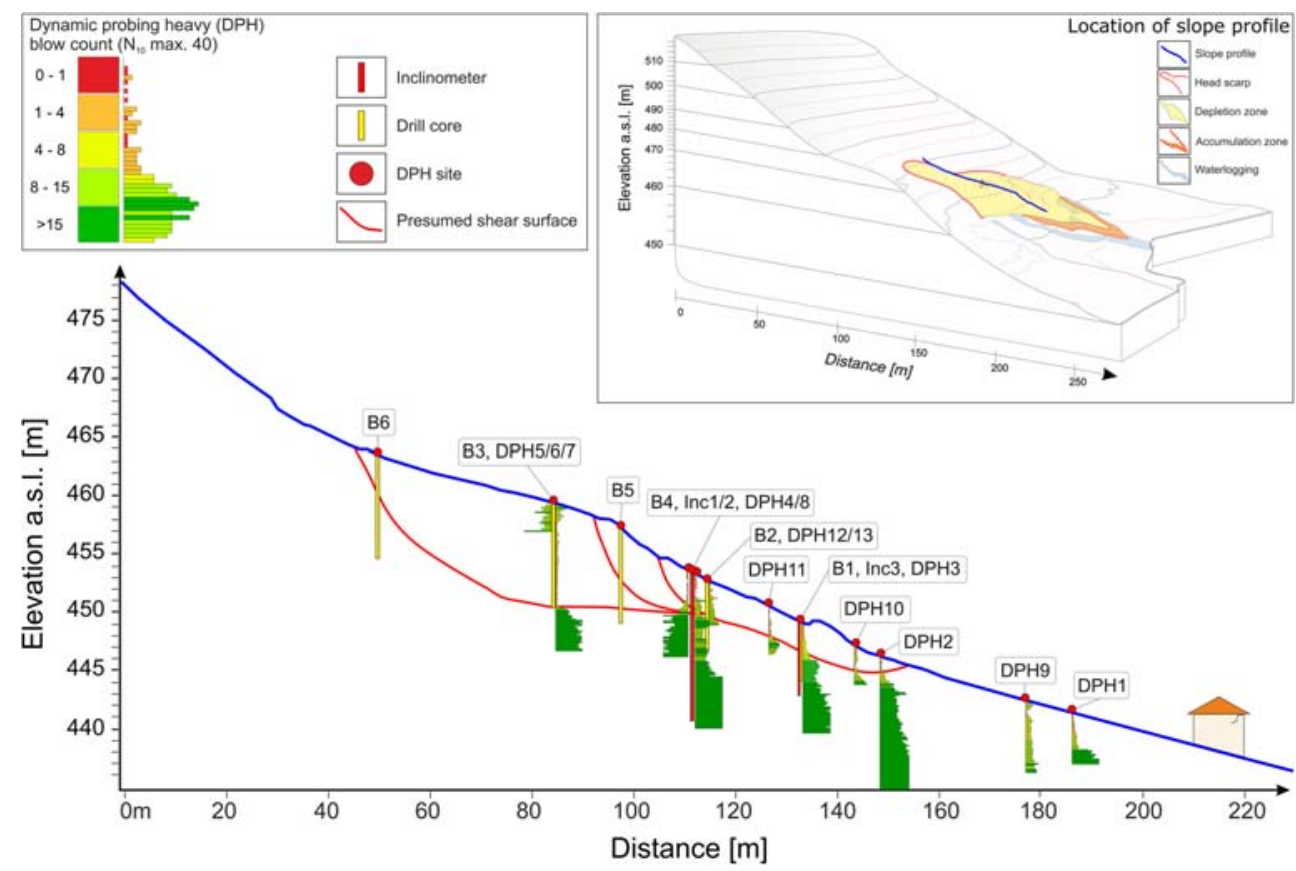


assessing in situ soil moisture content. In this preliminary study, the differences between the 2007 and December 2014 scans are determined only, and also only using a 2,5D DoD approach. In our current work, we are looking in much greater detail into the changes in the different periods. An innovative device that is currently being worked on is a permanent terrestrial laser scanning (pTLS) system (Canli et al. 2015). Most of the monitoring devices installed contain only point information, whereas TLS data enables spatially widespread information about surface changes over time. However, until now, the main constraint of TLS surveys is the temporal resolution. Data is being acquired only very sporadic due to labour costs and time requirements for field campaigns. With this newly developed system, high-resolution point cloud data is obtained once a day and processed in a fully automated way (from data transmission to vegetation filtering to change detection). Movement data is then correlated with a newly installed automatic inclinometer and rainfall data (both with 10-min measurement interval). For all automatic measurement devices, a reliable data infrastructure has been implemented by now. Permanent electricity and data transmission are available on the entire landslide area and data is transferred to a data server in Vienna in real-time; however, it has also been stored within a local server for backup. Ultimately, the data gained is used within further analyses including data correlation, threshold analysis and spatio-temporal slope stability analysis.

Acknowledgements Open access funding provided by University of Vienna. The authors want to thank in particular the municipal authorities of Gresten, especially Irmgard Plank. Additionally, we want to thank the landowner and the neighbouring families for their kind collaboration and their support of our investigations. Robert Peticzka and Christa Hermann are thanked for their aid in the laboratory analyses and for fruitful discussions. We are also grateful to the technical staff, particularly Oliver Szczech and Bamidele Ayoniyi, and to all participating students during fieldwork.

Funding information This study was kindly co-financed by the Geological Survey of the Federal State Government of Lower Austria, St. Pölten, Austria. The financial support of the University of Vienna for field equipment is deeply acknowledged.

Open Access This article is distributed under the terms of the Creative Commons Attribution 4.0 International License (http:// creativecommons.org/licenses/by/4.0/), which permits unrestricted use, distribution, and reproduction in any medium, provided you give appropriate credit to the original author(s) and the source, provide a link to the Creative Commons license, and indicate if changes were made.

\section{References}

Abellán A, Vilaplana JM, Calvet J, García-Sellés D, Asensio E (2011) Rockfall monitoring by terrestrial laser scanning - case study of the basaltic rock face at Castellfollit de la Roca (Catalonia, Spain) Natural Hazards and Earth System Sciences 11:829-841
Bassett R (2012) A guide to field instrumentation in geotechnics: principles, installation and reading. CRC Press, Boca Raton

Bell R, Thiebes B (2010) Untergrundbewegungen. In: Bell R, Mayer J, Pohl J, Greiving S, Glade T (eds) Integrative Frühwarnsysteme für gravitative Massenbewegungen (ILEWS). Monitoring, Modellierung, Implementierung. Klartext Verlag, Essen, pp 84-92, 265

Besl PJ, McKay ND (1992) A method for registration of 3-D shapes. IEEE Transactions on Pattern Analysis and Machine Intelligence 14:239-256. https://doi.org/10.1109/34.121791

Bronk Ramsey C, Scott EM, van der Plicht J (2013) Calibration for archaeological and environmental terrestrial samples in the time range 26-50 ka cal BP. Radiocarbon 55:2021-2027. https://doi. org/10.2458/azu_js_rc.55.16935

Burghaus S, Bell R, Kuhlmann H (2009) Improvement of a terrestric network for movement analysis of a complex landslide. Paper presented at the FIG Working Week 2009 - Surveyors Key Role in Accelerated Development, Eilat, Israel, 3. - 8. May

Camek T, Becker R, Öhl S (2010) Bodenfeuchte (TDR, Tensiometer). In: Bell R, Mayer J, Pohl J, Greiving S, Glade T (eds) Integrative Frühwarnsysteme für gravitative Massenbewegungen (ILEWS). Monitoring, Modellierung, Implementierung. 1. Aufl. edn. Klartext-Verlag, Essen, pp 92-100

Canli E, Höfle B, Hämmerle M, Thiebes B, Glade T (2015) Permanent 3D laser scanning system for an active landslide in Gresten (Austria) vol 17. European Geoscience Union General Assembly, Vienna, Austria

Coe JA, Godt JW (2012) Review of approaches for assessing the impact of climate change on landslide hazards. In: Eberhardt E, Froese C, Turner AK, Leroueil S (eds) Landslides and engineered slopes: protecting society through improved understanding: Proceedings of the 11th International and 2nd North American Symposium on Landslides and Engineered Slopes, Banff, Canada, 3-8 June. Taylor \& Francis Group, London, pp 371-377

Corsini A, Iasio C, Mair V (2012) Overview of 2001-08 GPS monitoring at the Corvara landslide and perspectives from 2010-11 use of HR X-band SAR (Dolomites, Italy). In: Eberhardt EB, Froese C, Turner $\mathrm{K}$, Leroueil S (eds) Landslides and engineered slopes : protecting society through improved understanding, vol 1. CRC Press/ Balkema, Leiden, pp 1353-1358

Crozier MJ (2010) Deciphering the effect of climate change on landslide activity: a review. Geomorphology 124:260-267. https://doi.org/10. 1016/j.geomorph.2010.04.009

Dunnicliff J (1993) Geotechnical instrumentation for monitoring field performance. Wiley, New York

Gance J, Malet JP, Dewez T, Travelletti J (2014) Target detection and tracking of moving objects for characterizing landslide displacements from time-lapse terrestrial optical images. Eng Geol 172: 26-40. https://doi.org/10.1016/j.enggeo.2014.01.003

Gance J, Malet JP, Supper R, Sailhac P, Ottowitz D, Jochum B (2016) Permanent electrical resistivity measurements for monitoring water circulation in clayey landslides. J Appl Geophys 126:98-115. https://doi.org/10.1016/j.jappgeo.2016.01.011

Gariano SL, Guzzetti F (2016) Landslides in a changing climate. Earth Sci Rev 162:227-252. https://doi.org/10.1016/j.earscirev.2016.08. 011

Gottschling P (2006) Massenbewegungen. In: Wessely G et al (eds) Geologie der österreichischen Bundesländer - Niederösterreich. Geologische Bundesanstalt, Wien, pp 335-340

Guzzetti F, Carrara A, Cardinali M, Reichenbach P (1999) Landslide hazard evaluation: a review of current techniques and their application in a multi-scale study, Central Italy. Geomorphology 31:181216

Höck V, Andrzej Ś, Gasiński MA, Bąk M (2005) Konradsheim limestone of the Gresten Klippen Zone (Austria): new insight into its stratigraphic and paleogeographic setting. Geol Carpath 56:237-244 
Jochum B, Lotter M, Ottner F, Tiefenbach K (2008) Geophysikalische und ingenieurgeologische Methoden zur Untersuchung von durch Massenbewegungen bedingte Bauschäden in Niederösterreich. BBK-Projekt NC-62/F (2007) und ÜLG-35 (2007). Endbericht zur Fallstudie Gresten (NÖ). Geological Survey of Austria (GBA); University of Natural Resources and Life Sciences (BOKU), Vienna, Austria

Jongmans D et al. (2008) Characterization of the Avignonet landslide (French Alps) using seismic techniques. In: 10th International Symposium On Landslides And Engineered Slopes, Xi'an, China, 2008-07-04. Taylor \& Francis, pp 395-401

Malet JP, van Asch TWJ, van Beek R, Maquaire O (2005) Forecasting the behaviour of complex landslides with a spatially distributed hydrological model. Nat Hazards Earth Syst Sci 5:71-85. https://doi.org/ 10.5194/nhess-5-71-2005

Massey CI, Petley DN, McSaveney MJ (2013) Patterns of movement in reactivated landslides. Eng Geol 159:1-19. https://doi.org/10.1016/ j.enggeo.2013.03.011

Mazzanti P, Bozzano F, Cipriani I, Prestininzi A (2015) New insights into the temporal prediction of landslides by a terrestrial SAR interferometry monitoring case study. Landslides 12:55-68. https://doi.org/ 10.1007/s10346-014-0469-x

Mikkelsen PE (1996) Field instrumentation. In: Turner AK, Schuster RL (eds) Landslides: investigation and mitigation. National Research Council (U.s.) Transportation Research Board Special Report 247. National Academy Press, Washington, pp 278-318

Monserrat O, Crosetto M, Luzi G (2014) A review of ground-based SAR interferometry for deformation measurement. ISPRS J Photogramm Remote Sens 93:40-48. https://doi.org/10.1016/j.isprsjprs.2014.04. 001

Montrasio L, Valentino R (2007) Experimental analysis and modelling of shallow landslides. Landslides 4:291-296. https://doi.org/10.1007/ s10346-007-0082-3

Mulas M, Petitta M, Corsini A, Schneiderbauer S, Mair FV, Iasio C (2015) Long-term monitoring of a deep-seated, slow-moving landslide by mean of C-band and X-band advanced interferometric products: the Corvara in Badia case study (Dolomites, Italy) International Archives of the Photogrammetry. Remote Sens Spat Inf Sci ISPRS Archives 40:827-829. https://doi.org/10.5194/isprsarchives-XL-7W3-827-2015

NOEL GV (2009) Digital elevation model (DEM) based on airborne laserscan data; raster resolution $1 \mathrm{~m}$. Federal State Government of Lower Austria, Department for Hydrology and Geoinformation, St. Pölten, Lower Austria

NOEL GV (2010) Digital orthophoto (20100711). Federal State Government of Lower Austria, Department for Hydrology and Geoinformation, St. Pölten, Lower Austria

Oberhauser R (1980) Der geologische Aufbau Österreichs. Springer Verlag, Wien [u.a]

Petley D (2012) Global patterns of loss of life from landslides Geology 40:927-930 doi:https://doi.org/10.1130/G33217.1

Petschko H, Bell R, Leopold P, Heiss G, Glade T (2013) Landslide inventories for reliable susceptibility maps in Lower Austria. In: Margottini C, Canuti P, Sassa K (eds) Landslide science and practice, Landslide inventory and susceptibility and hazard zoning, vol 1. Springer, Berlin Heidelberg, Berlin, Heidelberg, pp 281-286. https://doi.org/10.1007/978-3-642-31325-7_37

Petschko H, Brenning A, Bell R, Goetz J, Glade T (2014) Assessing the quality of landslide susceptibility maps - case study Lower Austria. Nat Hazards Earth Syst Sci 14:95-118. https://doi.org/10.5194/ nhess-14-95-2014

Pfeifer N, Mandlburger G, Otepka J, Karel W (2014) OPALS - a framework for airborne laser scanning data analysis computers. Environ Urban Syst 45:125-136. https://doi.org/10.1016/j.compenvurbsys. 2013.11.002
Prinz H, Strauß R (2011) Ingenieurgeologie. 5., bearbeitete und erweiterte Auflage edn. Spektrum Akademischer Verlag, Heidelberg

Prokop A, Panholzer H (2009) Assessing the capability of terrestrial laser scanning for monitoring slow moving landslides. Nat Hazards Earth Syst Sci (NHESS) 9:1921-1928. https://doi.org/10.5194/nhess-91921-2009

Reimer PJ et al (2013) IntCal13 and Marine13 radiocarbon age calibration curves 0-50,000 years cal BP. Radiocarbon 55:1869-1887. https://doi.org/10.2458/azu_js_rc.55.16947

Reyes CA, Fernández LC (1996) Monitoring of surface movements in excavated slopes. Paper presented at the Proceedings of the 7 th international symposium on landslides 17-21 June, Trondheim, Norway,

Riegl LMS (2017) Datasheet RIEGL VZ-6000

Ruttner A, Schnabel W (1988) Geologische Karte der Republik Österreich 1:50.000 Blatt 71 Ybbsitz. Geologische Bundesanstalt, Wien

Schnabel W (1980) Die Geologie des Voralpengebietes im Abschnitt Waidhofen an der Ybbs - Ybbsitz - Gresten vol 6. Musealverein Waidhofen an der Ybbs, Waidhofen, Ybbs

Schnabel W (1992) New data on the Flysch Zone of the Eastern Alps in the Austrian sector and new aspects concerning the transition to the Flysch Zone of the Carpathians. Cretac Res 13:405-419

Schnabel W (1999) The flysch zone of the Eastern alps vol 49. Verlag der Geologischen Bundesanstalt (GBA), Wien

Schnabel W, Krenmayr H-G, Mandl GW, Nowotny A, Roetzel R, Scharbert S (2002) Geologische Karte von Niederösterreich 1: 200.000. Geologische Bundesanstalt, Wien, Österreich

Schweigl J (2013) Gresten, Krause (Gst.Nr.1999/1), Bramreiter (Gst.Nr.1999/6) u.Plank (Gst.Nr.1999/7) Katastrophenschaden 2006, Rutschung Salcher, geologischer Abschlussbericht zu den Vermessungen. (BD1-G-142/001-2007) (intern). Geological office of the Federal State Government of Lower Austria,

Schweigl J, Hervás J (2009) Landslide mapping in Austria. Joint Research Centre - Institute for Environment and Sustainability. https://doi.org/10.2788/85150

Schwenk H (1976) Erhebungsbericht und Gutachten des geologischen Dienstes der Baudirektion. (No. BD-3120/1-1975) (intern). Geological office of the Federal State Government of Lower Austria,

Schwenk H (1979) Erhebungsbericht und Gutachten des geologischen Dienstes der Baudirektion. (No. BD-G-78156) (intern). Geological office of the Federal State Government of Lower Austria,

Schwenk H (1992) Massenbewegungen in Niederösterreich 1953-1990 Jahrbuch der Geologischen Bundesanstalt 135:597-660

Springman S, Kienzler P, Casini F, Askarinejad A (2009) Landslide triggering experiment in a steep forested slope in Switzerland. In: ElMossallamy Y, Shahien M, Hamza M, International Society of Soil M, Geotechnical E, Jam īyah al-Jughrāfīyah a-Mry (eds) Proceedings of the 17 th International Conference on Soil Mechanics and Geotechnical Engineering: The Academia \& Practice of Geotechnical Engineering: 5-9 October 2009, Alexandria, Egypt, vol 2. IOS Press, Amsterdam, pp 1698-1701

Stark TD, Choi H (2008) Slope inclinometers for landslides. Landslides 5:339. https://doi.org/10.1007/s10346-008-0126-3

Steger S, Brenning A, Bell R, Petschko H, Glade T (2016) Exploring discrepancies between quantitative validation results and the geomorphic plausibility of statistical landslide susceptibility maps. Geomorphology 262:8-23. https://doi.org/10.1016/j.geomorph. 2016.03.015

Stumpf A, Malet JP, Allemand P, Pierrot-Deseilligny M, Skupinski G (2015) Ground-based multi-view photogrammetry for the monitoring of landslide deformation and erosion. Geomorphology 231:130 145. https://doi.org/10.1016/j.geomorph.2014.10.039

Supper R et al (2014) Geoelectrical monitoring: an innovative method to supplement landslide surveillance and early warning. Near Surface 
Geophysics 12:133-150. https://doi.org/10.3997/1873-0604. 2013060

Thenius E (1974) Geologie der österreichischen Bundesländer in kurzgefaßten Einzeldarstellungen. Niederösterreich. Verhandlungen der Geologischen Bundesanstalt: Bundesländerserie $=$ Geologie der österreichischen Bundesländer in kurzgefaßten Einzeldarstellungen. Geologische Bundesanstalt, Wien, Österreich.

Thiebes B (2012) Landslide analysis and early warning systems: local and regional case study in the Swabian Alb, Germany. Recognizing Outstanding PhD Research. Springer, Dodrecht, Springer Theses

Thiebes B, Glade T (2016) Landslide early warning systemsfundamental concepts and innovative applications. In: Aversa S, Cascini L, Picarelli L, Scavia C (eds) Landslides and engineered slopes - experience, theory and practice -, vol 3. Associazione Geotecnica Italiana, Rome, pp. 1903-1912.

Tilch N (2014) Identifizierung gravitativer Massenbewegungen mittles multitemporaler Luftbildauswertung in Vorarlberg und angrenzender Gebiete Jahrbuch der Kaiserlich-Königlichen Geologischen Bundesanstalt 154:21-39.

Tilch N, Schwarz L, Winkler E (2013) Gefahren (hinweis) karten für gravitative Massenbewegungen (Hangrutschungen und Hangmuren) Herausforderungen, Limitierungen, Chancen. Berichte der Geologischen Bundesanstalt 100:47-53

Travelletti J, Oppikofer T, Delacourt C, Malet JP, Jaboyedoff M (2008) Monitoring landslide displacements during a controlled rain experiment using a long-range terrestrial laser scanning (TLS)
International Archives of the Photogrammetry. Remote Sens Spat Inf Sci ISPRS Archives 37:485-490

University of Vienna (2014) Digital elevation model (DEM) based on terrestrial laserscan data (Riegl VZ 6000); final raster resolution of DEM $10 \mathrm{~cm}$. Vienna, Austria

Van Den Eeckhaut M, Verstraeten G, Poesen J (2007) Morphology and internal structure of a dormant landslide in a hilly area: the Collinabos landslide (Belgium). Geomorphology 89:258-273

Weber L (1997) Flächendeckende Beschreibung der Geologie von Österreich 1:500.000 im Vektorformat. Exzerpt (Basiskarte Geologie) aus der Metallogenetischen Karte von Österreich 1: 500.000. Geologische Bundesanstalt, Wien. Österreich.

Wessely G et al (2006) Geologie der österreichischen Bundesländer Niederösterreich. Geologie der österreichischen Bundesländer, Geologische Bundesanstalt, Wien, Österreich

Widder RW (1988) Zur Stratigraphie, Fazies und Tektonik der Grestener Klippenzone zwischen Ma. Neustift und Pechgraben/OÖ. In: Oberösterreichs M-uF (ed) Oberösterreichische GEO-Nachrichten, Beiträge zur Geologie, Mineralogie und Paläontologie von Oberösterreich, vol 3, pp 11-55

Yin Y, Wang H, Gao Y, Li X (2010a) Real-time monitoring and early warning of landslides at relocated Wushan Town, the Three Gorges Reservoir, China. Landslides 7:339-349. https://doi.org/10.1007/ s10346-010-0220-1

Yin Y, Zheng W, Liu Y, Zhang J, Li X (2010b) Integration of GPS with InSAR to monitoring of the Jiaju landslide in Sichuan, China. Landslides 7:359-365. https://doi.org/10.1007/s10346-010-0225-9 